\title{
UPPER CATCHMENT OF BRIBIN UNDERGROUND RIVER HYDROGEOCHEMISTRY (GUNUNG SEWU KARST, GUNUNG KIDUL, JAVA, INDONESIA)
}

\author{
Tjahyo Nugroho Adji ${ }^{1}$ \\ ${ }^{1}$ Karst Research Group, Faculty of Geography, Gadjah Mada University, Indonesia, adji@ geo.ugm.ac.id
}

\begin{abstract}
This research was conducted within Bribin underground river, the primary river in the Gunung Sewu karst area, Gunung Kidul, Java, Indonesia. The main purpose of this study is to describe hydrogeochemical processes that occur at the upstream of Bribin River. In addition, this study also differentiates hydrogeochemical dominant processes, which come about in rainy season and dry season. Study area boundary is the upper rainfall catchment of Bribin River that is focused on three locations: Pentung River (surface), Luweng Jomblangan, and Gilap Cave. Discharge measurements for one year period are conducted to define discharge hydrograph. Furthermore, baseflow separation analysis is conducted to determine the percentage of base flow (PAD) throughout the year. Water sampling for hydrogeochemical analysis is taken every month to represent dry season and rainy season condition. To describe the hydrogeochemical processes, scatter plot analysis with small sample size is conducted. The result shows that within dry season, dominant hydrogeochemical process is water rock interaction that indicates by: achieving maximum level of $\mathrm{Ca}^{2+}-\mathrm{HCO}_{3}{ }^{-}$; strong relationship between discharge increment and PAD reduction; strong relationship between increasing of $\mathrm{Ca}^{2+}-\mathrm{HCO}_{3}^{-}$and increasing of PAD. In addition, strong relationship between the increase in $\mathrm{Ca}^{2+}-\mathrm{HCO}_{3}{ }^{-}$and reduction of carbondioxide in water as well as minimum level of carbondioxide gas in water at the peak of dry season, is also present. In rainy season, hydrogeochemical process shifted from water-rock interaction to dilution by precipitation as a result of rain water supply through conduit system channel, which is characterized by: declining in $\mathrm{Ca}^{2+}-\mathrm{HCO}_{3}^{-}$when discharge increase; increasing $\mathrm{Ca}^{2+}-\mathrm{HCO}_{3}^{-}$when discharge decrease; low correlation of spesific conductivity vs $\mathrm{Ca}^{2+}-\mathrm{HCO}_{3}^{-}$; low correlation of PAD vs $\mathrm{Ca}^{2+}-\mathrm{HCO}_{3}^{-}$when discharge increase, strong correlation between declining in PAD by increasing of $\mathrm{CO}_{2}$ in the water, and rising of $\mathrm{CO}_{2}$ when discharge increase.
\end{abstract}

\section{Introduction}

Bribin Underground River is firstly published by MacDonalds and Partners (1984). It is located within Gunung Sewu Karst area, which is initially introduced by Danes (1910) and Lehmann (1936). This karst is characterized by the development of conical hills (kegelkarst), the positive formation of blunt, and no steep or often termed as sinusoidal dome. Kegelkarst by Sweeting (1972) is categorized as part of tropical karst type. Several other geomorfologist strengthen Lehmann opinion i.e. Flathe and Pfeiffer (1965); Balazs (1968, 1971); Verstappen (1969), and Waltham et al. (1983). In fact, Balazs (1968) confirms that the number of hills in this region amounted to more than 40,000 hills with a density of about 30 hills $/ \mathrm{km}^{2}$. Recent publications related to this karst region are conducted by Haryono and Day (2004), Haryono and Adji (2004), Adji and Haryono (1999), Adji et al. (1999), Ahmad, et al. (2005), and Urushibara-Yoshino and Yoshino (1997).

The largest underground river systems in this karst region is Bribin-Baron system, which reached discharge amounted to 8000 liters/sec (MacDonald and Partners, 1984). This underground river system is the most important river systems in the Gunung Sewu karst (Figure 1). Meanwhile, the Bribin River on the upstream system performs the largest discharge and a focus for the fulfillment of local domestic water. Demographically, the number of people who depend on this water supply system is more than 200,000 people. In addition, Bribin River catchment was firstly defined by Fakultas Kehutanan (1993) bounded on the upstream (north) by a massive old-volcanic mountain, in the west by the ancient Ponjong- Polje (Srijono and Aldilla, 2006), while the southern and eastern boundaries have not undefined yet. This paper reports on result of the first detail-quantitative evaluation of karst aquifer hydrogeochemistry within the upper part of Bribin River, with the primary focus on identifying the relation between hydrochemical parameters to provide understanding of aquifer characteristic and behavior in this area.

\section{Climate and Hydrogeological Setting}

Bribin River catchment is administratively located in Gunung Kidul Regency, DIY Province, Indonesia. As it is located on a tropical region, the knowledge of climatic conditions, especially rainfall and temperature impinge on the water input component associated with the karst hydrogeochemistry condition. Not so much research related to climate conditions in the Gunung Sewu. The most recent researches on global climate conditions in Gunung Sewu are conducted by Verstappen (1997) and Urushibara-Yoshino and Yoshino (1997). Previous studies related to climate in the Quaternary period in the vicinity of the study (Java Island) performed by Urushibara-Yoshino (1995) and Verstappen (1975, 1994), Dam (1994), Morley (1982), and Budel (1975). Meanwhile, information about climate conditions in Bribin River catchment are found in publications by Adji and Nurjani (1999), Suryanta (2001), MacDonalds and Partners (1984), BMG (2000, in Sutikno and Tanudirjo, 2006), and Fakultas Kehutanan (1993). 
These studies show the monthly average temperature in Bribin River catchment area ranged from $22.12{ }^{\circ} \mathrm{C}$ to $26.97{ }^{\circ} \mathrm{C}$. Meanwhile, the annual rainfall in Gunung Sewu ranges from 2000 to $2500 \mathrm{~mm} /$ year from data obtained at 12 rain gauge station in the period of 1947-2000. The research brief that take place by Adji (2010) indicates that the air humidity in Bribin River catchment ranges between $60-90 \%$ with temperatures between $24-28{ }^{\circ} \mathrm{C}$.

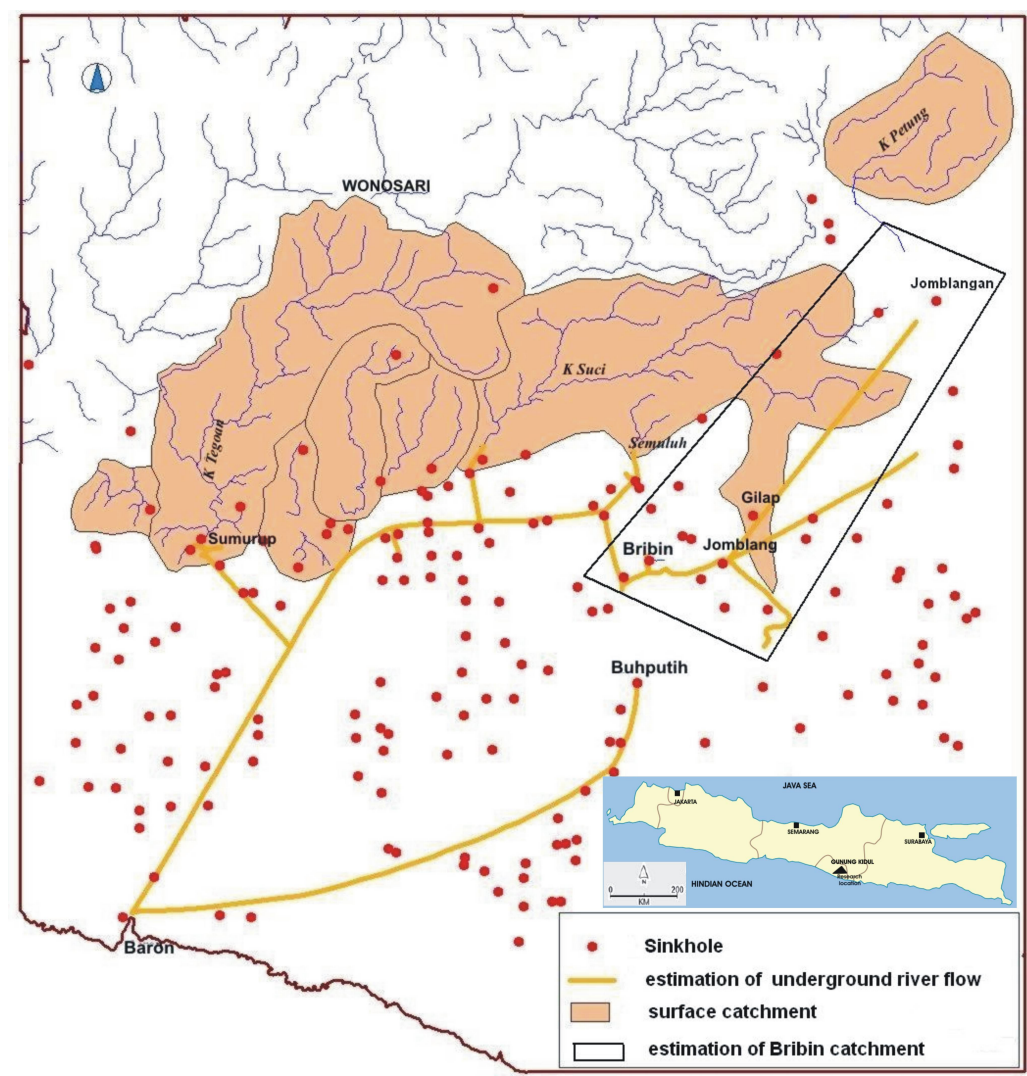

Figure 1. Bribin River Catchment and Bribin-Baron System (MacDonalds and Partners, 1984)

Geologically, the study area is dominated by Miocene limestone of the Wonosari Formation, which consists of massive coral reef limestone in the south and bedded chalky limestone in the north (Balazs 1968; Bemmelen 1970; Waltham et al. 1983; Surono et al. 1992). The results of 1:50,000 scale aerial photo interpretation and image of 1:1,000,000 scale ERS conducted by Kusumayudha (2005), shows that the moment structure consisting of thick cracks, faults, and fractures in Gunungsewu have a general direction moves the structure fracture or fault northwest-southeast and northeastsouthwest. The existence of regional structure is then divided the area into blocks bounded by faults that also set the hydrogeological system since the creation of low-level and high-level configuration (Kusumayudha, 2005). The catchment of Bribin River included in the Wonosari-Baron Subsystems of hydrogeology that have bedrock configuration (volcanic rock) as graben that has direction around the northeast-southwest (Figure 2).

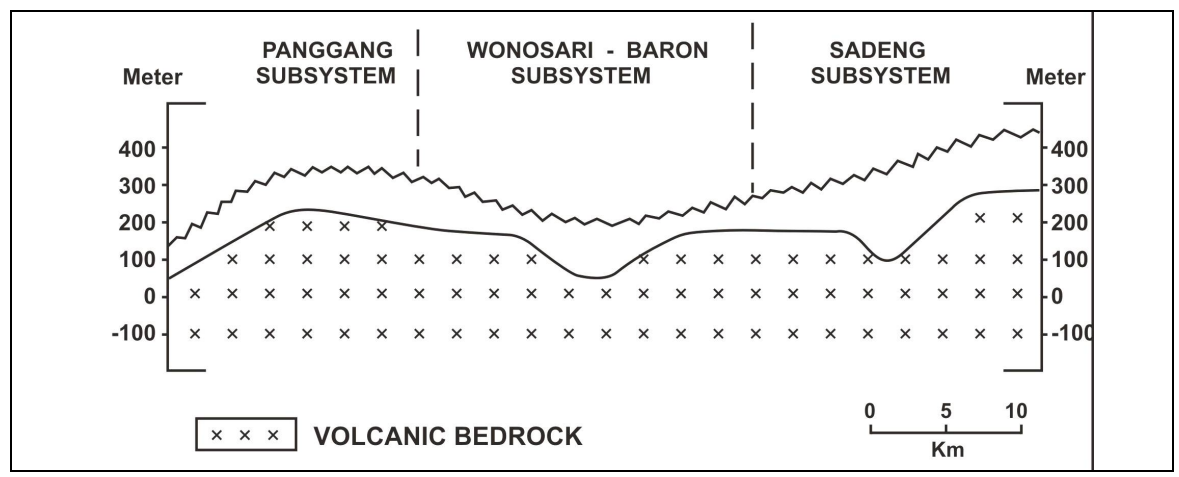

Figure 2. Hydrogeological Conceptual Model of West-Eastern region Gunungsewu (Kusumayudha, 2005) 
Bribin River describes by the MacDonalds and Partners (1984) starts from a surface (Pentung River) that disappears to some sinkholes in Sawahombo area. This river then emerges as a cenote in Luweng Jomblangan, which then emerges again in Gilap Cave, Luweng Jomblang Banyu, Luweng Jurangjero, and last appeared in Bribin Cave before comes out as a large resurgence at Baron Beach. In the segment between Luweng Jurang Jero and Bribin Cave, it leaks out to Ngreneng Cave, which also flows into the Beach Baron afterwards (Figure 3). In this study, the Pentung River, Luweng Jomblangan, and Gilap Cave regarded as the upper area of Bribin River catchment. According to Adji (2005) and Adji (2010), Pentung River is intermittent due to the lack of baseflow supply from the old-volcanic aquifer. As a result, large runoff occurs after rain events and the river discharge is very low during the dry season. This river then disappears into the underground river which later appeared in Luweng Jomblangan. Luweng Jomblangan is a cenote which is located only about 500 meters from the sinkhole loss of the Pentung River that consequence to similar discharge fluctuations between these two points. In addition, Luweng Jomblangan minimum discharge is about 80 liters/sec (Fakultas Kehutanan, 1993). Second occurrence of the River Bribin after Luweng Jomblangan is Gilap Cave point. The entrance of this cave is in a collapse doline with 200 meters of diameter. Gilap Cave is always watery throughout the year (perennial), with minimum discharge is about 6 liters/sec, while the maximum discharge of approximately 350 liters/sec.

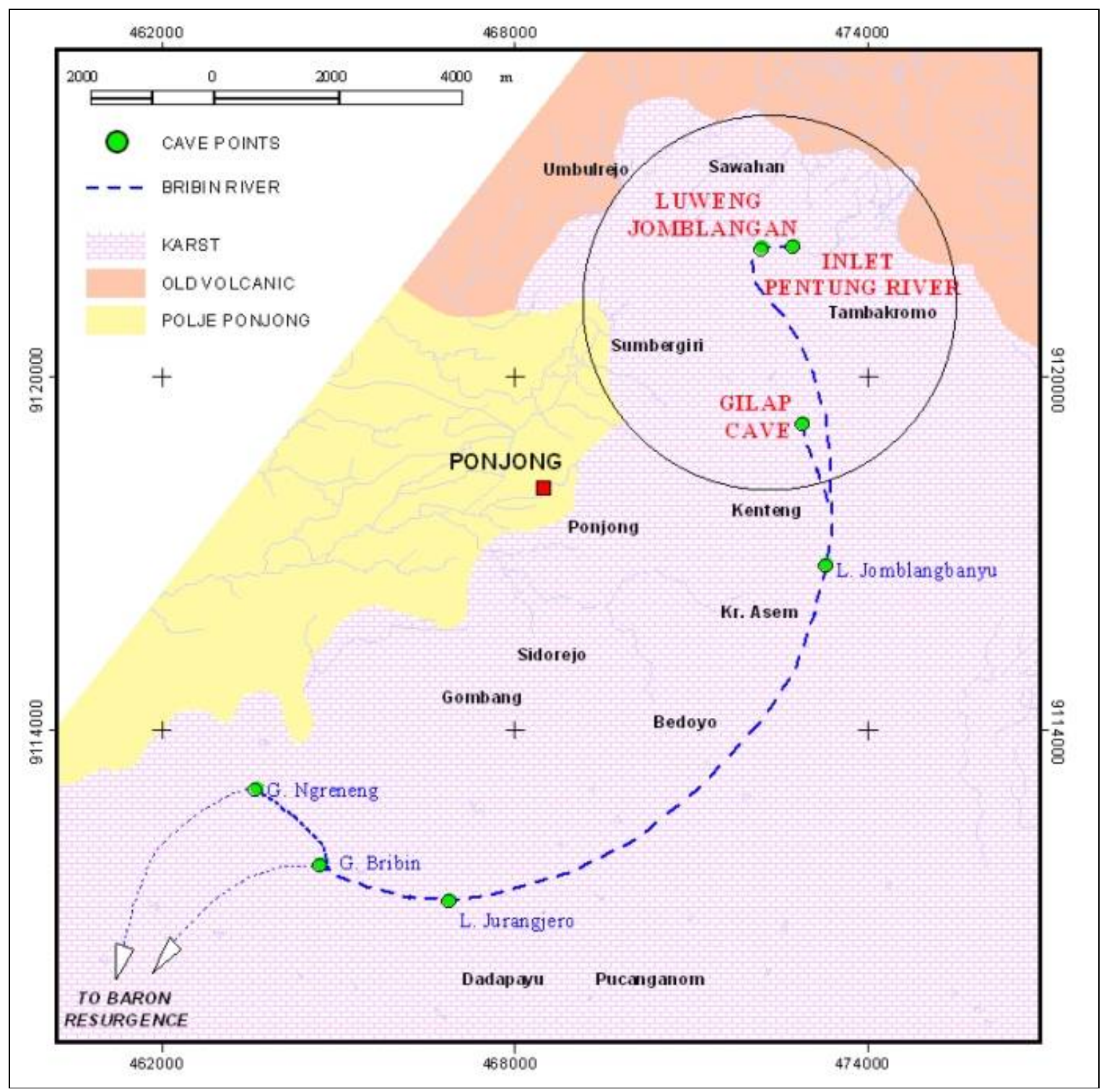

Figure 3. Bribin River System

\section{Methods}

The boundary of study area is the estimated surface area of Bribin River rainfall catchment, and the research focuses on the three locations within upper area of catchment, which are Pentung River, Luweng Jomblangan, and Gilap Cave. Furthermore, recording of water level fluctuations and discharge measurement is carried out to obtain the discharge 
hydrograph throughout the year. Separation of base flow is conducted using the automated base flow separation by digital filtering method (Eckhardt, 2005), on the basis of a recession constant value in the hydrograph, which is then correlated to the value of Base Flow Indices (BFI) within karst aquifer, the formula used are:

$$
q_{b(i)}=\frac{\left(1-B F I_{\max }\right) a q_{b(i-1)}+(1-a) B F I_{\max } q_{i}}{1-a B F I_{\max }}
$$

where $q_{b(i)}$ is the baseflow at time $i, q_{b(i-1}$ is the baseflow at the previous time $i-1, q_{i}$ is the total flow at time $i, a$ is the recession constant and $\mathrm{BFI}_{\max }$ is the maximum baseflow that can be measured or performed. To find the constant of recession used the formula:

$$
Q_{t}=Q_{0} e^{-\alpha t}
$$

where $Q_{t}$ is the flow rate at time $t, Q_{0}$ is the initial discharge in recession segment, and $\alpha$ is a constan. Furthermore, $e^{-\alpha}$ may be replaced by $k$, which is known as a recession constant or depletion factor. This constant is often used as an indicator of the continuity of baseflow (Nathan and McMahon, 1990). Then, the value of $k$ compared with the classification of karst underground river recession by Worthington (1991, in Giliesson, 1996). In this research, due to the difficulties of field conditions, water level data logger could not be installed at Luweng Jomblangan point, so that the baseflow proportion is not calculated.

Water sampling is conducted one time/month during a year to cover two seasons (rainy and dry seasons). Chemical analysis of samples in the laboratory include the cations $\mathrm{Ca}^{2+}, \mathrm{Mg}^{2+}, \mathrm{Na}^{+}, \mathrm{K}^{+}$and anions $\mathrm{Cl}^{-}, \mathrm{SO}_{4}{ }^{2-}$, dan $\mathrm{HCO}_{3}^{-}$. . Volumetric method is used for the element of $\mathrm{Ca}^{2+}, \mathrm{Mg}^{2+}, \mathrm{CO}_{3}^{-}$and $\mathrm{SO}_{4}{ }^{2-}$; spectrophotometric method for $\mathrm{HCO}_{3}^{-}$, and flamefotometri for $\mathrm{Na}^{+}$and $\mathrm{K}^{+}$. Furthermore, analysis of Saturation Indices (SI) is conducted to determine the nature of water to the level of carbonate rock dissolution with respect to $\mathrm{CaCO}_{3}$ mineral, assisted with software Netpath (Plummer, et al, 1991) with the formula as follows.

$$
\mathrm{SI} \mathrm{CaCO}_{3}=\log \frac{\left[\mathrm{CO}_{3}^{-}\right]\left[\mathrm{Ca}^{2+}\right]}{\mathrm{Ksp} \mathrm{CaCO}_{3}}
$$

where $\left[\mathrm{CO}_{3}^{-}\right]$is the carbonate ion activity, $\left[\mathrm{Ca}^{2+}\right]$ is the calcium ion activity; $\mathrm{Ksp}$ is the solubility product of $\mathrm{CaCO}_{3}=10^{-8,48}$. Another analysis is the calculation of $\mathrm{PCO}_{2}$ (partial pressure of carbondioxide), which is assumed to have reached equilibrium of water samples (Stumn and Morgan, 1981; Drever, 1988; White, 1988) in all samples, assisted with software Wateq-4F (Ball and Nordstrom , 1991), is determined.

$$
\mathrm{P}_{\mathrm{CO} 2}=\left[\mathrm{HCO}_{3}^{-}\right]\left[\mathrm{H}^{+}\right] / \mathrm{K}_{1} \mathrm{~K}_{\mathrm{CO} 2}
$$

where $\mathrm{PCO}_{2}$ is partial pressure of carbondioxide gas in water; $\left[\mathrm{HCO}_{3}^{-}\right]$is the activity of bicarbonate ions, $\left[\mathrm{H}^{+}\right]$is hydrogen ion activity; $\mathrm{K}_{1}$ is the equilibrium constant reaction solvent at $25^{\circ} \mathrm{C}$, and $\mathrm{K}_{\mathrm{CO} 2}$ is the equilibrium constant of $\mathrm{CO}_{2}$ in water at $25^{\circ} \mathrm{C}$. To describe the hydrogeochemical processes, scatter plot analysis with small sample size (non-discrete parameters) is conducted, including: (i) discharge-major ion concentration, (ii) specific conductivity-calcium and bicarbonate, (iii) sodium-chloride, (iv) discharge-baseflow, (v) baseflow-log PCO2, and (vi) baseflow-calcium and bicarbonate.

\section{Result and Discussion}

Table 1. shows the hydrochemical properties of the upper part of Bribin River for 12 months between March 2006 and April 2007.

Pentung River as a surface river performs the characteristic of dissolved elements temporal variation be different compared to an underground river, which generally characterized by obvious fluctuations between dry and rainy season. However, in Pentung River, fluctuations encountered are not too strict in the dry season and during the rainy season. The same condition also found in Luweng Jomblangan due to its location closes to Pentung River. Here, conductivity and dissolved elements fluctuations similar to those found in the Pentung River. The conductivity value during rainy season is very low $(200 \mu \mathrm{mhos} / \mathrm{cm})$, even if during dry season it reaches peak value of almost $500 \mu \mathrm{mhos} / \mathrm{cm}$, similar to those found in underground river. Just as that found in the Bribin Cave (Adji, 2010), when the rain towards the end of the dry season, Luweng Jomblangan and Gilap Cave shows declining of discharge leading to the dominance of baseflow (diffuse flow), which is characterized by increasing of dissolved elements constituent in water due to diffuse flow recharge as saturated water infiltration from karst aquifers. When entering a period of rain, the dominance of the baseflow is reduced and fluctuates depending on the period of flood events to occur. Similar pattern found in the Bribin Cave (Adji, 2010), which is also shown on the temporal variation of dissolved calcium and bicarbonate that tend to increase slowly in the dry season and then dropped dramatically at the peak of the rainy season and then increased again at the end of the rainy season 2007 . 
Table 1. One-year hydrogeochemistry of three major points within upper Bribin River

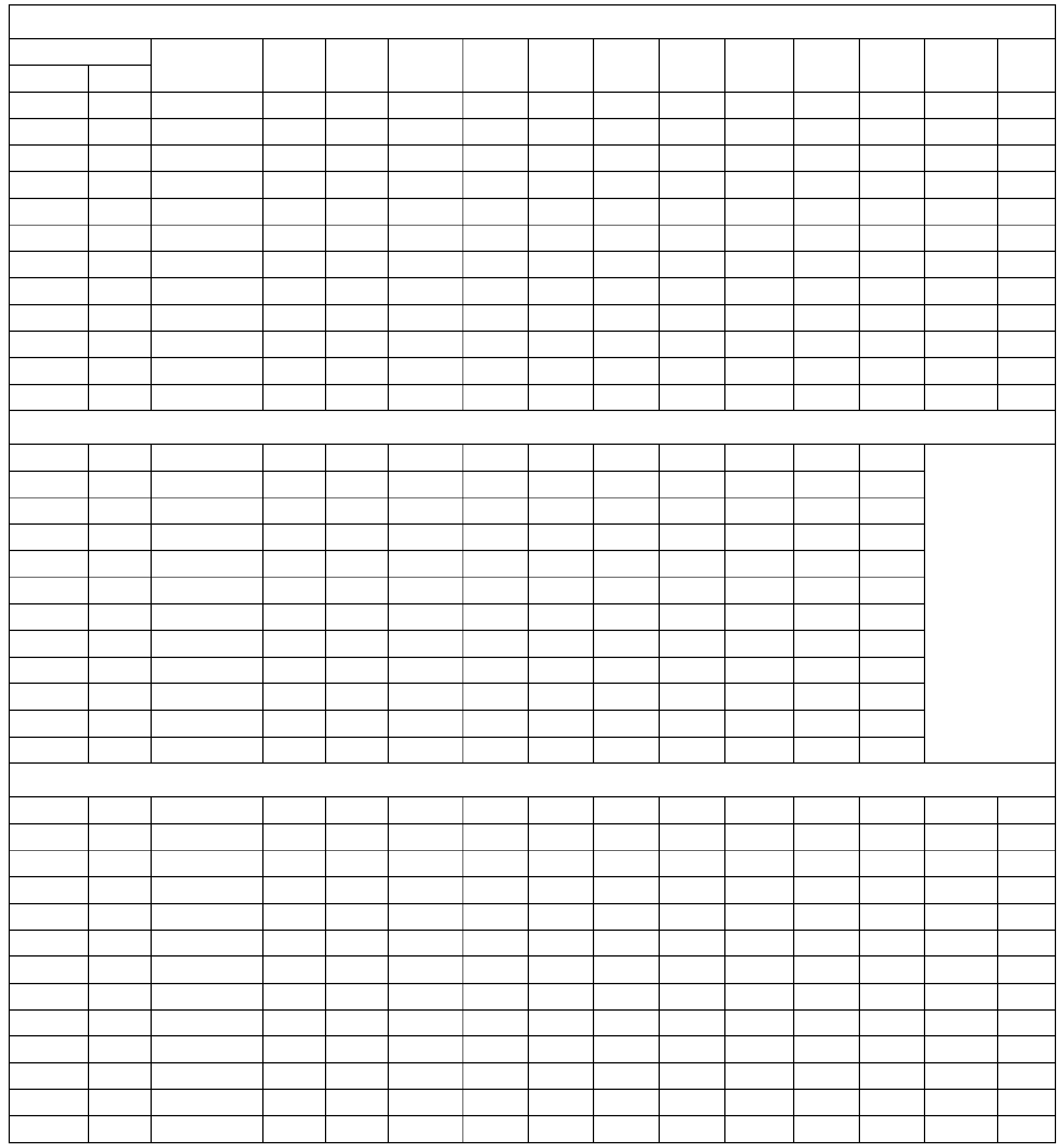

* conductivity are expressed in $\mu$ mhos/cm; major elements in ppm; $\mathrm{Q}=$ discharge in lt/sec; PAD= (baseflow/total discharge) in \%

Scatter plot of conductivity- calcium and bicarbonate

Scatter plot of conductivity, calcium and bicarbonate in Pentung River, Luweng Jomblangan, and Gilap Cave are shown in Figure 3, 4, and 5. 


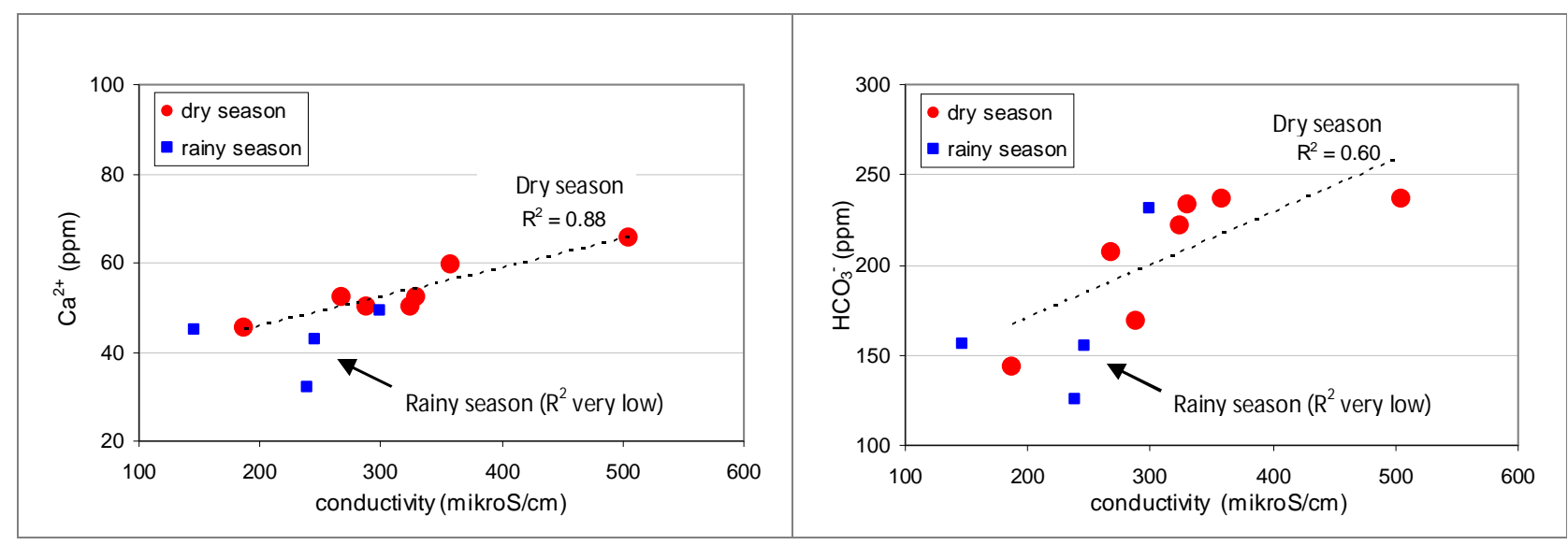

Figure 3. Linear relationships between specific conductivity versus calcium (left) and specific conductivity versus bicarbonate (right), along the year for Pentung River
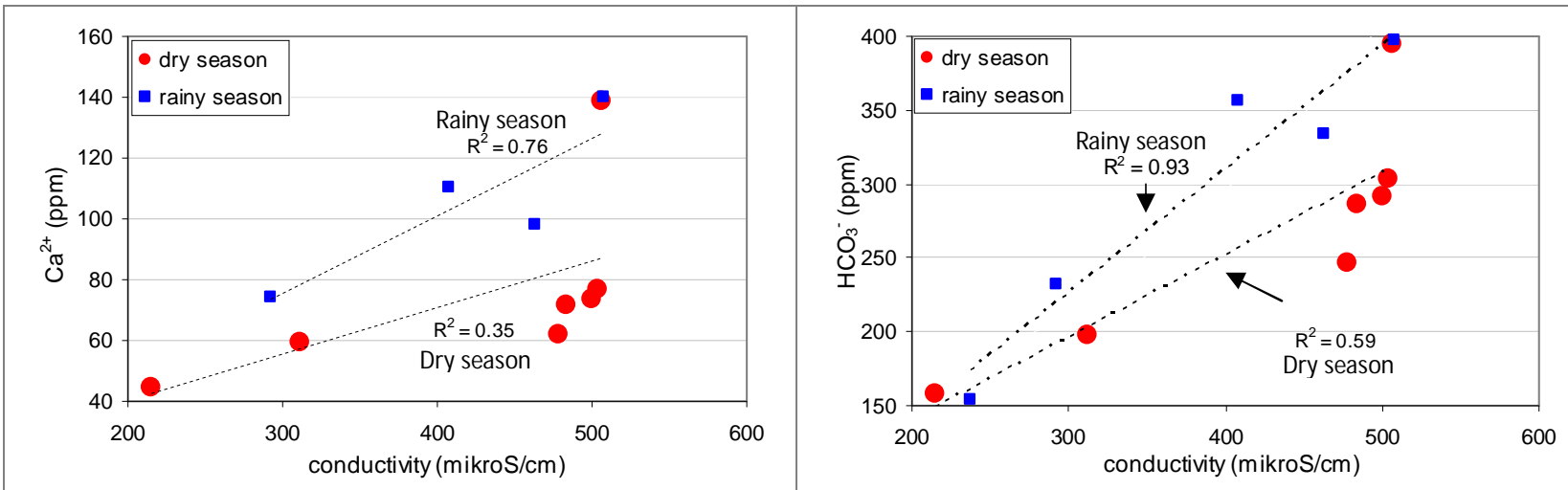

Figure 4. Linear relationships between specific conductivity versus calcium (left) and specific conductivity versus bicarbonate (right), along the year for Luweng Jomblangan

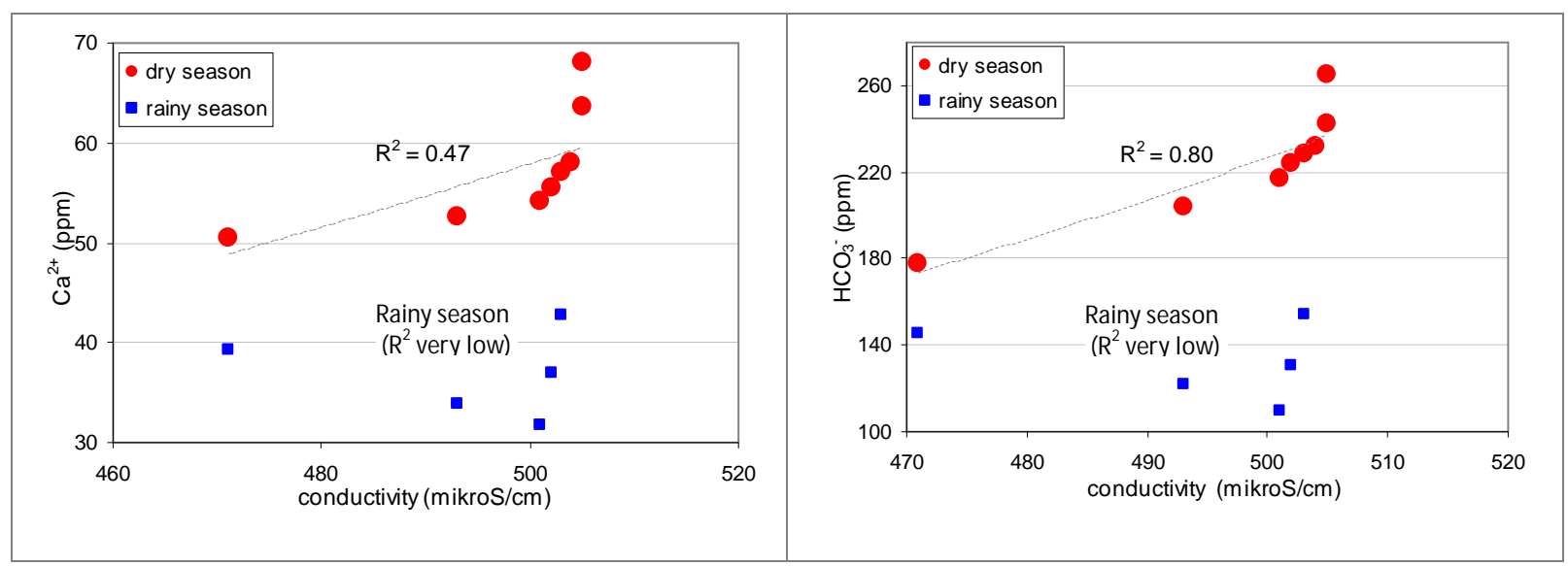

Figure 5. Linear relationships between specific conductivity versus calcium (left) and specific conductivity versus bicarbonate (right), along the year for Gilap Cave

According to Figure 3, 4, and 5, it seems that the relationship between specific conductivity and calcium or bicarbonate generally has a positive relationship in the dry season, with correlation value $\left(\mathrm{R}^{2}\right)$ by $70 \%$, even more. Conversely, $\mathrm{R}^{2}$ value in rainy season is small or negative. This indicates that the positive relationship related to water-rock interaction process to occur predominantly during the dry season, i.e. when there is dominance of diffuse flow than during 
the rainy season that is affected by the flow of the conduit system, resulting in a mixing process and also it may be by the process of dilution by precipitation. From the pictures it is also seen that the values of dissolved calcium and bicarbonate as well as specific conductivity during the dry season is much greater than that occur during the rainy season. Different characteristic found in Luweng Jomblangan, that the value of dry season $\mathrm{R}^{2}$ value is very low. This occurs because the flow component in Luweng Jomblangan is a mixture of surface streams and karst aquifers that have different carbonate mineral saturation.

\section{Scatter plot sodium-chloride}

Scatter plot of sodium-chloride in Pentung River, Luweng Jomblangan, and Gilap Cave are shown in Figure 6. Analysis of scatter plots between $\mathrm{Na}^{+}$and $\mathrm{Cl}^{-}$indicate that there is a clear separation of plotting position, i.e. samples of rainy season and early dry season has a relative position close to the 1:1 line, while the samples from September and November 2006 (drought peak) shows the position which is utmost from the line ratio of 1:1. It shows strong water-rock interaction process due to the weakening of the dominance of rain and is replaced by the diffuse flow component from karst aquifer.

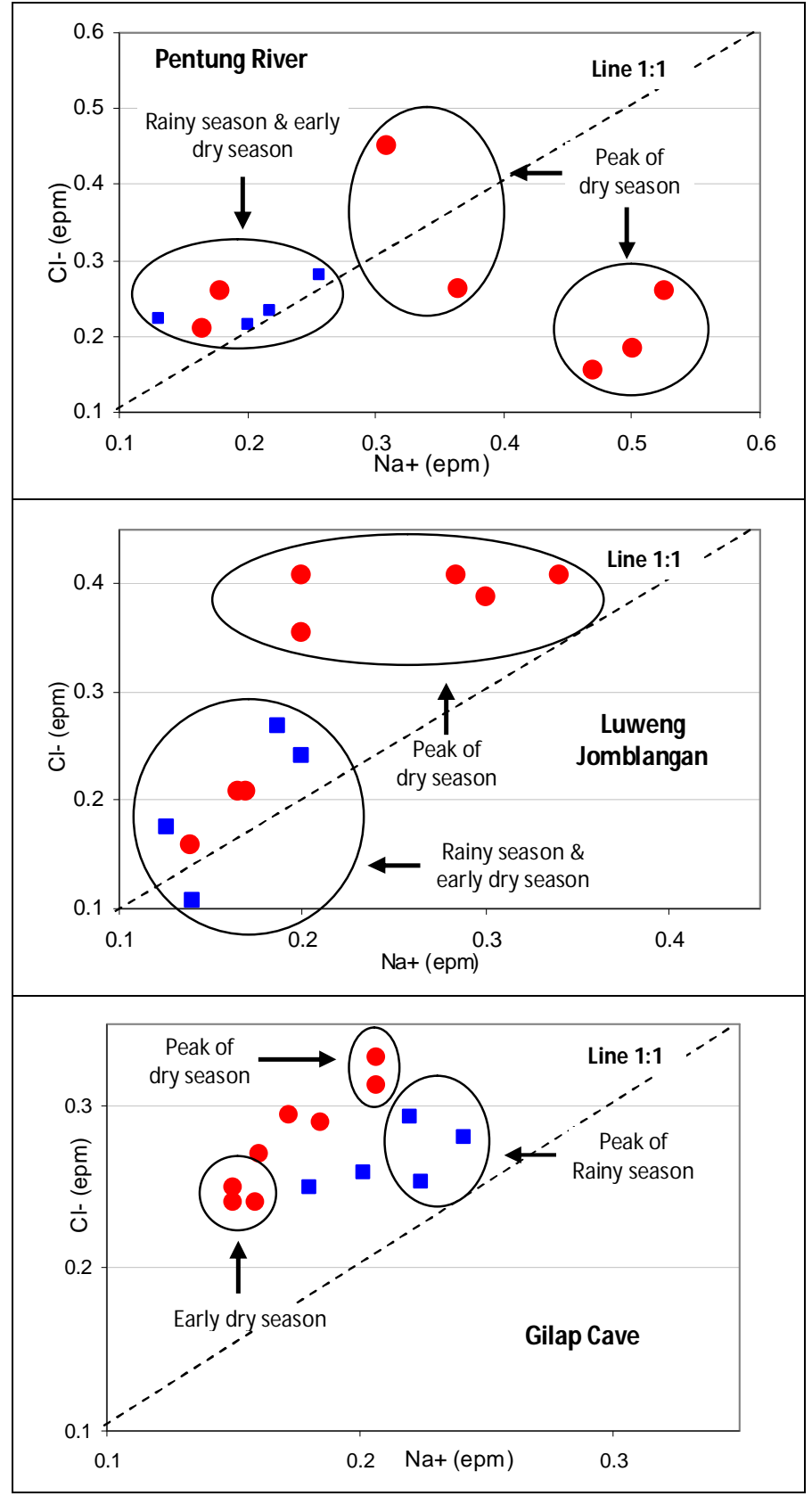

Figure 6. Scatter plot of sodium-chloride along the year for Pentung River (above), Luweng Jomblangan (middle), and Gilap Cave 


\section{Scatter plot PAD-discharge}

Scatter plot of PAD-discharge in Pentung River and Gilap Cave are presented in Figure 7. Meanwhile, discharge measurement is not conducted in Luweng Jomblangan in order that PAD is not calculated. In general, decreasing in discharge related to increasing of diffuse flow percentage (PAD). This negative correlation also occurs in rainy season, although the correlation is relatively somewhat smaller. However, in Gilap Cave, there are two rainy season samples put in close proximity to the discharge-PAD linear line of dry season. These two samples are taken during the rainy season rather than during flood events (beginning and end of rainy season), thus indicating the existence of water-rock interaction process. Next, Pentung River performs a strong relationship between decreasing of discharge and PAD increasing (negative relationship), especially during the dry season $\left(\mathrm{R}^{2}=0.99\right)$. Furthermore, because of the influence of surface runoff, which is controlled by rainfall, the correlation between discharge and the PAD during the rainy season decreases slightly $\left(\mathrm{R}^{2}=\right.$ $0.84)$.
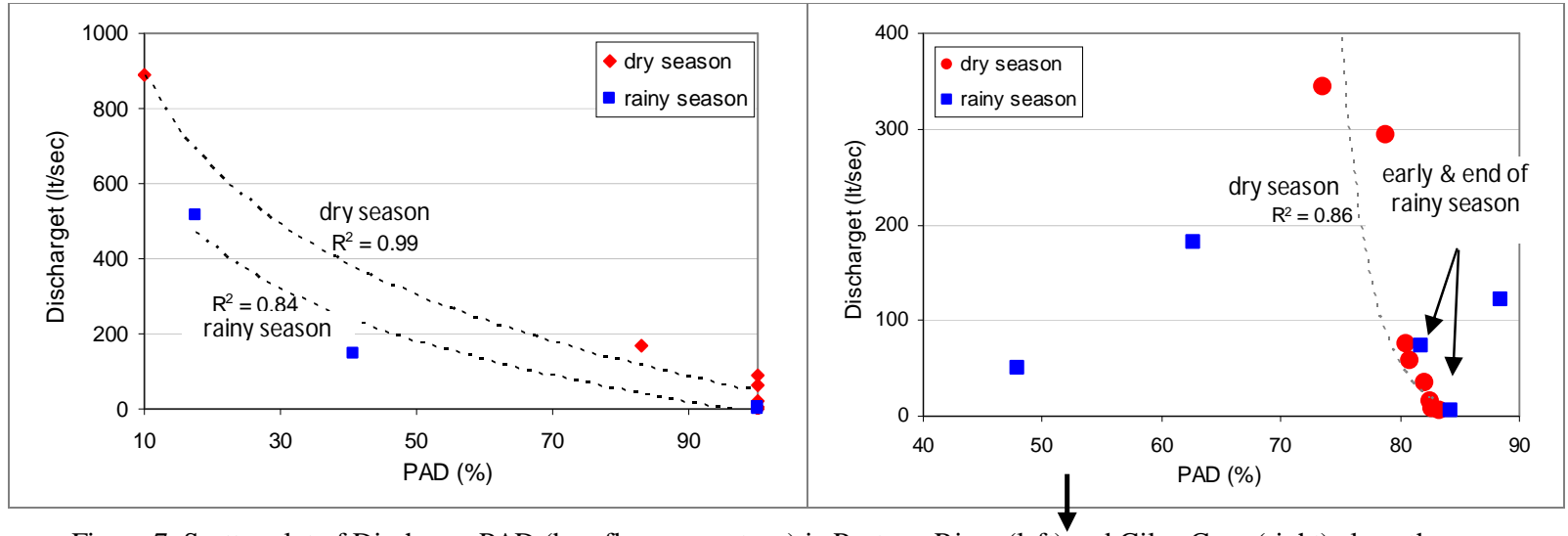

Figure 7. Scatter plot of Discharge-PAD (baseflow percentage) in Pentung River (left) and Gilap Cave (right) along the year

Scatter plot calcium and bicarbonate $-P A D$

Scatter plot of calcium and bicarbonate -PAD in Pentung River and Gilap Cave are shown in Figure 8 and 9.

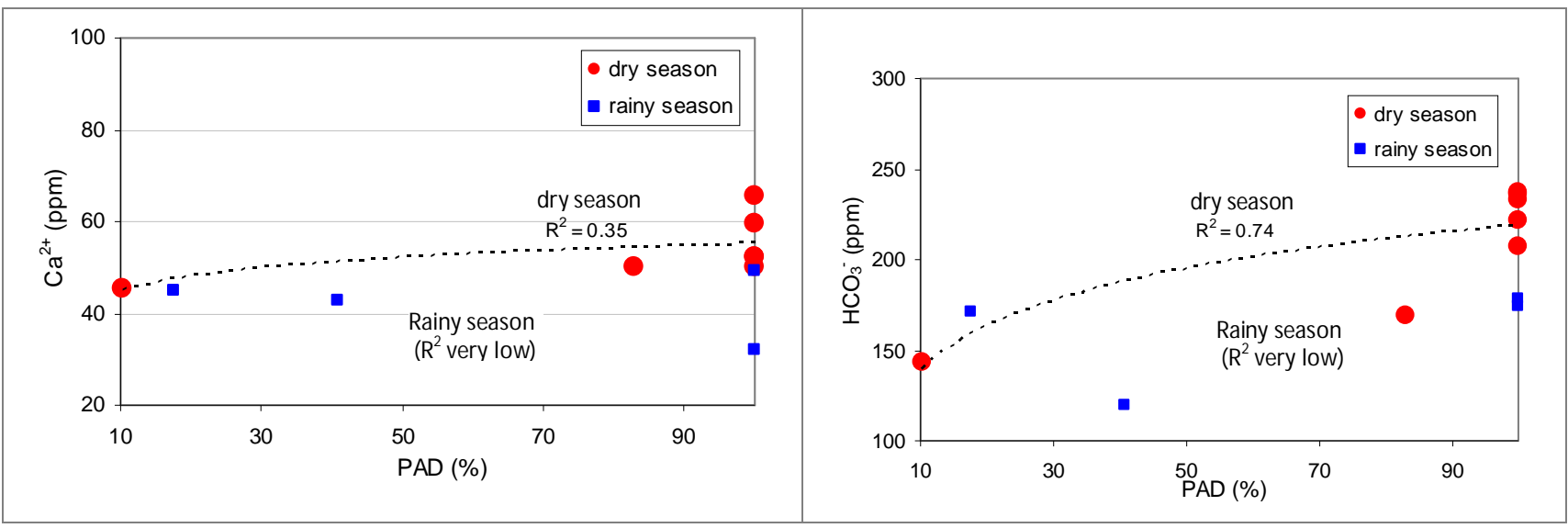

Figure 8. Scatter plot of PAD-Calcium (left) and PAD-Bicarbonate (right) in Pentung River along the year

The relationship of calcium and bicarbonate-PAD within rainy season in Pentung Rivers shows positive relationship with very small correlation or negative (Figure 8). During the dry season it turns into positive relationship, but the correlation is not as big as that found Cave Gilap. This is caused by the differences in flow composition and fluctuation that recharge into river. Also, it is caused by conduit flow characteristic, which performs time lag longer than the overland flow occurs to recharge Pentung River from its catchment area. According to Figure 9, it seems that the PAD in Gilap Cave during the rainy season varies between $47-88 \%$, whereas during the dry season the range is between $73-83 \%$. This suggests that conduit channels exist in the system to contribute conduit flow during rainy periods. This positive correlation between PAD-calcium and bicarbonate during rainy and dry season indicates that PAD in Gilap Cave controls to calcium and bicarbonate constituent. 


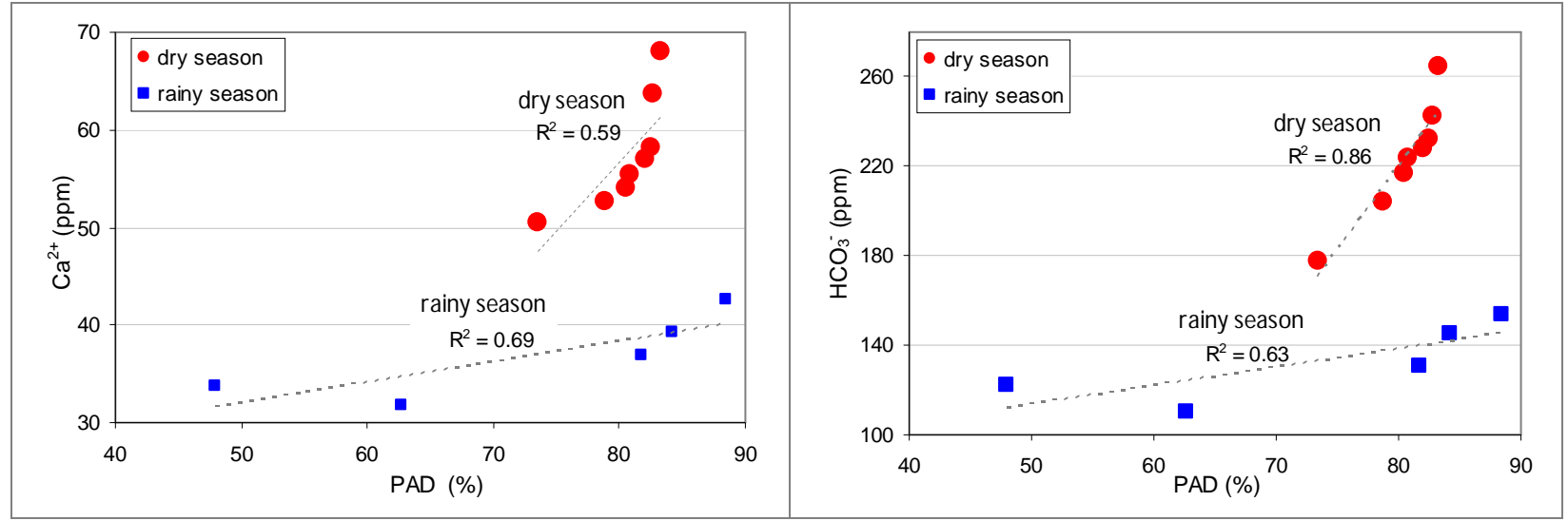

Figure 9. Scatter plot of PAD-Calcium (left) and PAD-Bicarbonate (right) in Gilap Cave along the year

Scatter plot PAD-log $\mathrm{PCO}_{2}$

Scatter plot of PAD-log $\mathrm{PCO}_{2}$ in Pentung River and Gilap Cave are shown in Figure 10.

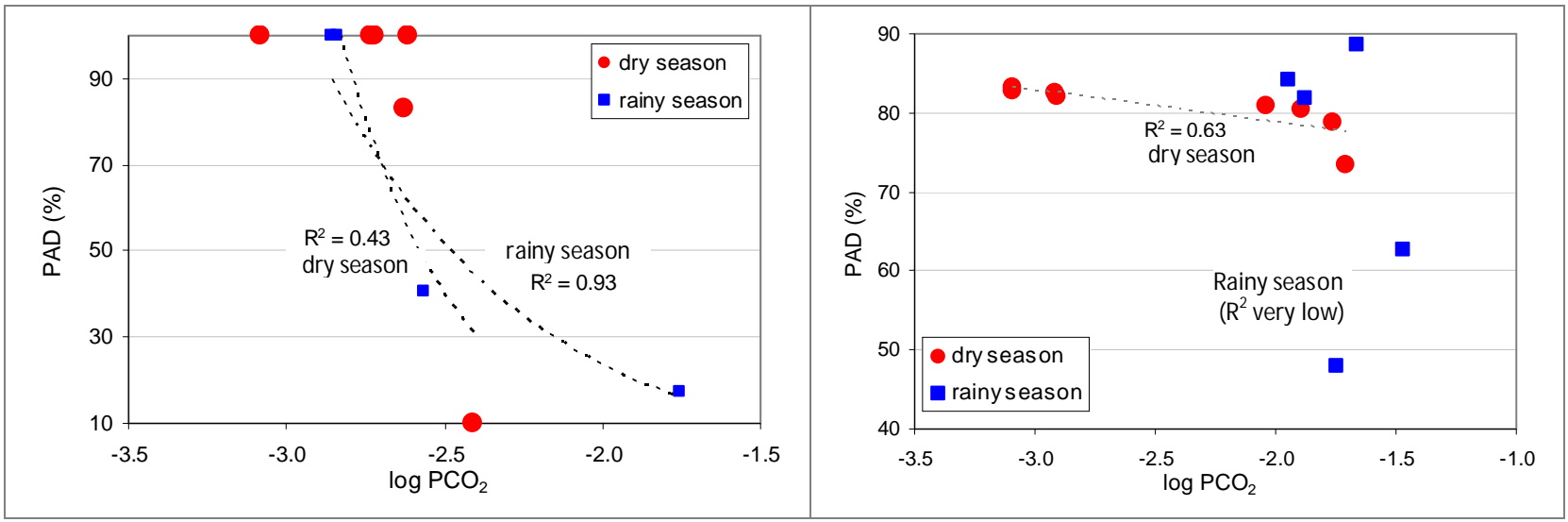

Figure 10. Scatter plot of PAD-log $\mathrm{PCO}_{2}$ in Pentung River (left) and (right) in Gilap Cave along the year

Correlation of $\log \mathrm{PCO}_{2}$-PAD in the Pentung River have $\mathrm{R}^{2}$ values of about 0.9 , because the system of air-waterinterface in Pentung River is open, so every time there is transfer of carbondioxide gas into the water. In Pentung River also no carbon dioxide gas that is used to dissolve the limestone as found in Gilap Cave aquifer. In Gilap Cave, value of log $\mathrm{PCO}_{2}$ variations shows a declining trend and reaches its lowest level during the peak of dry season (September-November), which then rises when the rainy season comes, and fluctuates depending on the variation of flooding that occurred. When, it is correlated to $\mathrm{PAD}$, it performs negative relationship, meaning that the value of $\log \mathrm{PCO}_{2}$ decreases while the percentage of baseflow (PAD) in Cave Gilap increases (Figure 10). During the dry season, there is a more significant relationship between the $\mathrm{PCO}_{2}$ and PAD in Gilap Cave compare to that within rainy season $\left(\mathrm{R}^{2}\right.$ value of 0.63 compared with 0.15 in the rainy season). This indicates that the process of water-rock interaction occurs predominantly during the dry season. Several other processes that occur during the rainy season are the dilution by precipitation as indicated by the falling value of PAD and the supply of carbondioxide gas through conduit system.

Scatter plot of calcium and bicarbonate-log $\mathrm{PCO}_{2}$

Scatter plot of calcium and bicarbonate-log $\mathrm{PCO}_{2}$ in Pentung River and Gilap Cave are shown in Figure 11 and 12. 


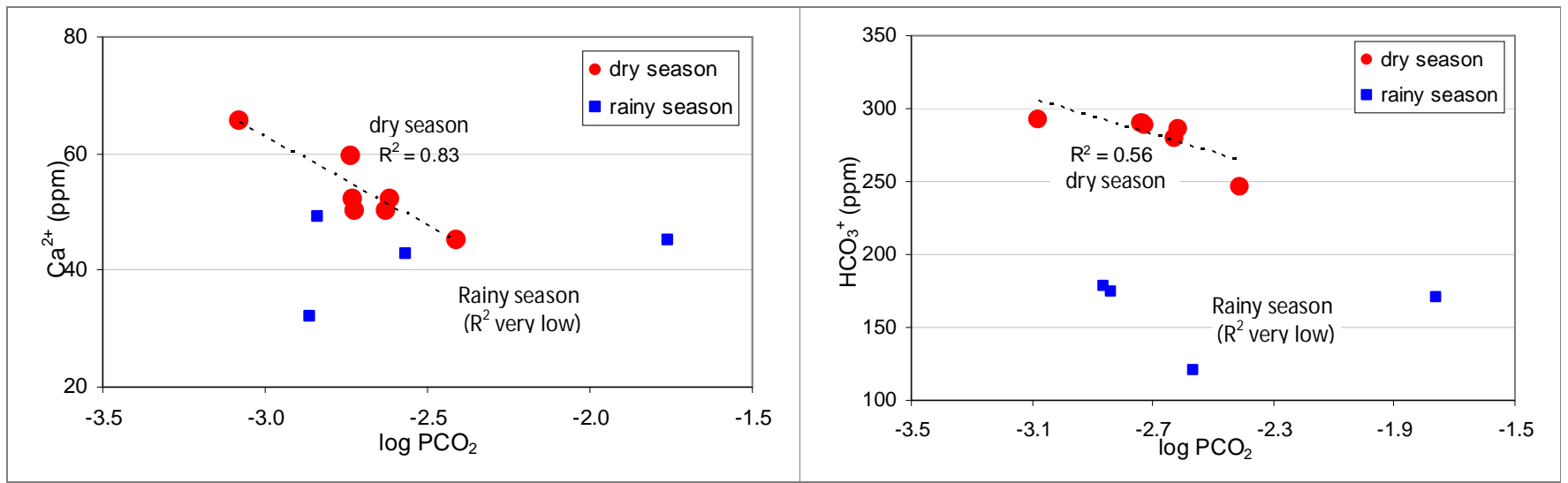

Figure 11. Scatter plot of calcium (left) and bicarbonate (right)-log $\mathrm{PCO}_{2}$ in Pentung River along the year

Negative correlation is also found in the relationship between calcium and bicarbonate-log $\mathrm{PCO}_{2} \cdot \mathrm{R}^{2}$ value low during the rainy season shows the dominance of fast-changing flow conduit, when floods supplies water from karst surface to recharge underground streams and reduce PAD (baseflow). Conversely, the value of $\mathrm{R}^{2}$ is quite high during the dry season, indicates that the effect of carbondioxide gas is more likely to occur during the rainy season and decreases the influence of water-rock interaction process. This is supported by the facts in Ngreneng Cave as described by Adji (2010). In Ngreneng Cave, the immense of direct runoff supplies Ngreneng Cave during the rainy season through its conduit system decreases the relationship between calcium and bicarbonate-log $\mathrm{PCO}_{2}$.
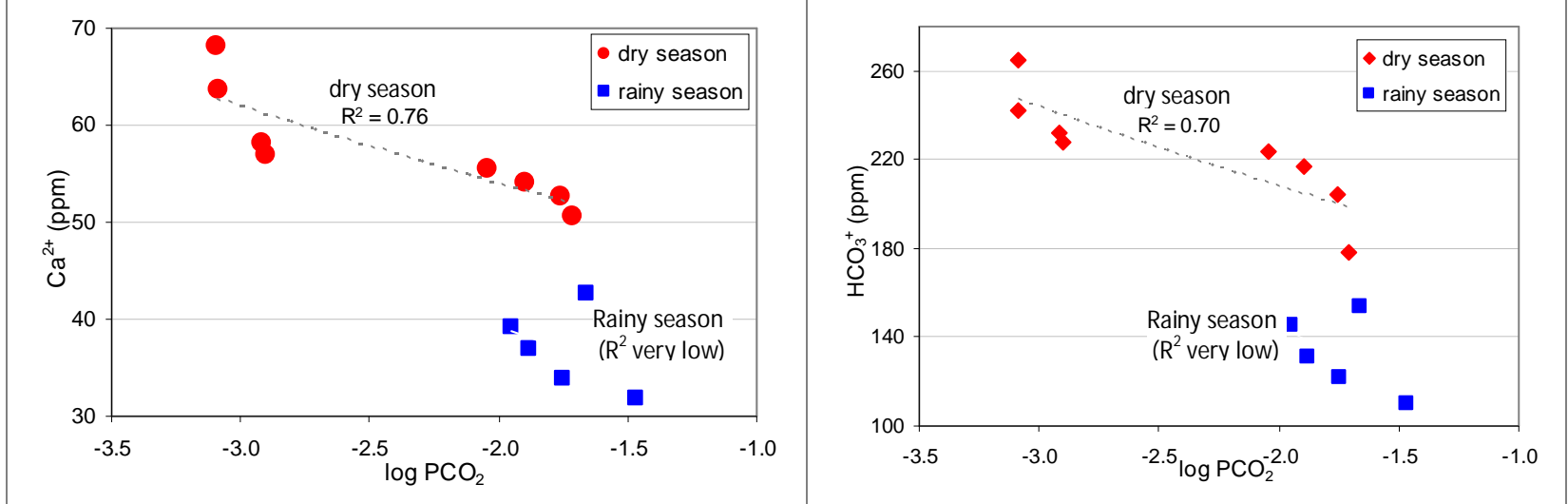

Figure 12. Scatter plot of calcium (left) and bicarbonate (right)-log $\mathrm{PCO}_{2}$ in Gilap Cave along the year

\section{Conclusion}

From the scatter plot discussion of relationship between hydrogeochemical parameters within the upper part of Bribin River catchment area, spatially and temporally, it is concluded that:

(1) in dry season, there is a strong relationship between the percentage of baseflow (PAD) with the calcium and bicarbonate dissolved in water. It can be perceived from the high correlation between DHL and calcium-bicarbonate which specified strong water-rock interaction process. Another thing that indicates strong relationship between hydrogeochemical characteristics and baseflow condition is the high correlation between PAD and calcium-bicarbonate. In addition, the level of correlations value during the dry season also influenced by the sampling point's position along Bribin River.

(2) in rainy season, hydrogeochemical process shifted from water-rock interaction process to dilution by precipitation process due to the rain water supply through conduit system channel. This fact indicated by the declining value of correlation between the PAD and calcium-bicarbonate and DHL- calcium-bicarbonate. Another factor to affect underground river hydrochemistry is the difference in spatial position and flow characteristics along Bribin River. Then, the summary of hydrogeochemical processes within rainy and dry season of Bribin River upper catchment is shown in Table 2. 
Table 2. Summary of hydrogeochemistry of three major points in upper catchment of Bribin River

\begin{tabular}{|c|c|c|}
\hline Season & $\begin{array}{l}\text { Hydrogeochemical } \\
\text { processes }\end{array}$ & Hydrogeochemistry characteristics parameters \\
\hline Dry & water rock interaction & $\begin{array}{l}\text { - } \mathrm{Ca}^{2+} \text { dan } \mathrm{HCO}_{3}^{-} \text {constituent increase to reach its peak during dry season } \\
\text { - strong relationship between discharge increment and } \mathrm{PAD} \text { reduction } \\
\text { - strong relationship between increasing of } \mathrm{Ca}^{2+} \text { and } \mathrm{HCO}_{3}^{-} \text {and increasing of } \\
\text { PAD } \\
\text { - minimum level of carbondioxide gas in water at the peak of dry season } \\
\text { - the chemical composition of the dry season peak dissimilar to early dry season } \\
\text { - strong relationship between the increase in } \mathrm{Ca}^{2+} \text { and } \mathrm{HCO}_{3}^{-} \text {and reduction of } \\
\text { carbondioxide in water }\end{array}$ \\
\hline Rainy & $\begin{array}{l}\text { - dilution by precipitation } \\
\text { - water-rock interaction } \\
\text { - difusion of carbondioxide gas }\end{array}$ & $\begin{array}{l}\text { - the dominance of conduit flow during floods, and domination of diffuse flow } \\
\text { during non-flood and recession period } \\
\text { - the declining in } \mathrm{Ca}^{2+} \text { dan } \mathrm{HCO}_{3}^{-} \text {when discharge increase, and increasing } \mathrm{Ca}^{2+} \\
\text { dan } \mathrm{HCO}_{3}^{-} \text {when discharge decrease } \\
\text { - rising of carbondioxide gas when discharge increase } \\
\text { - low correlation of spesific conductivity vs } \mathrm{Ca}^{2+} \text { and } \mathrm{HCO}_{3}^{-} \\
\text {- low correlation of PAD vs } \mathrm{Ca}^{2+} \text { dan } \mathrm{HCO}_{3}^{-} \text {when discharge increase } \\
\text { - high correlation of PAD vs } \mathrm{Ca}^{2+} \text { dan } \mathrm{HCO}_{3}^{-} \text {when discharge decrease } \\
\text { - a strong correlation between declining in } \mathrm{PAD} \text { by increasing of } \mathrm{CO}_{2} \text { in the } \\
\text { water during the rainy season }\end{array}$ \\
\hline
\end{tabular}

\section{Acknowledgement}

This article presented is another result as a part of Dissertation to the Doctoral Degree in Geography Study Program, Faculty of Geography, Gadjah Mada University. The author wishes to fully express his profound gratitude to his supervisor, Professor Sudarmadji, Professor Suratman and Dr. Heru Hendrayana for their supports from the beginning until the finalization of this research. Also, sincerely thank and appreciation is due to Bagus Yulianto, Badi Hariadi, Lili Ismangil, Dr. Eko Haryono, Zaenuri, Ari Purwanto, and Acintyacunyata Speleological Club (ASC) and its members for their accompaniment during carrying out the fieldwork.

\section{References}

Adji T.N. dan Nurjani, E., 1999. Optimasi Airtanah karst Sebagai Pemasok Air Domestik Pada Kawasan Kritis Air di Gunung Kidul, Laporan Penelitian, Fakultas Geografi UGM (tidak dipublikasikan)

Adji, T.N. and Haryono, E., 1999. Konflik Antara Pemanfaatan Batugamping dan Konservasi Sumberdaya Air Das Bribin di Wilayah Karst Gunung Sewu, Makalah Lokakarya Nasional Menuju Pengelolaan Sumberdaya Wilayah Berbasis Ekosistem Untuk Mereduksi Konflik Antar Daerah, Yogjakarta, , Fakultas Geografi, Universitas Gadjah Mada, September 1999

Adji, T.N., 2005, Agresivitas Airtanah Karst Sungai Bawah Tanah Bribin, Gunung Sewu, Indonesian Cave and Karst Journal, Vol. 1 No1, HIKESPI

Adji, T.N., 2010. Variasi Spasial-Temporal Hidrogeokimia dan Sifat Aliran Untuk Karakterisasi Sistem Karst Dinamis di Sungai Bawah Tanah Bribin, Kabupaten Gunung Kidul, DIY, Disertasi, Fakultas Geografi, Universitas Gadjah Mada, Yogyakarta, http://tjahyo-adji.staff.ugm.ac.id/tjahyo_adji_S3.pdf

Adji, T. N., 2010. Spatial and Temporal Variation of Hydrogeochemistry and Karst Flow Properties to Characterize Karst Dynamic System in Bribin Underground River, Gunung Kidul Regency, DIY Province Java, Indonesia. Summary, Dissertation in Geography Study Program. Graduate School of Geography, Gadjah Mada University, Yogyakarta

Adji, T.N., Haryono, E., Woro, S, 1999, Kawasan Karst dan Prospek Pengembangannya di Indonesia, Seminar PIT IGI di Universitas Indonesia, 26-27 Oktober 1999

Ahmad, M.L., Haryono, E., Suprojo, S.W., 2005, Geomorfologi Karst Mayor antara Telaga Sanglen dan Kamal, Kabupaten Gunung Kidul, DIY, Gunung Sewu-Indonesian Cave and Karst Journal, Vol. 1 No. 1, HIKESPI, Indonesia

Balazs, D., 1968. Karst Regions in Indonesia: Karszt-Es Barlangkutatas, Volume V. Budapest, Globus nyomda, 61 p.

Balazs, D., 1971, Intensity of the Tropical Karst Development Based on Cases of Indonesia, Karszt-Es Barlangkutatas, Volume VI. Budapest, Globus nyomda, 67 p. 
Ball, J.W., Nordstrom, D.K., 1991. User's manual for WATEQ4F with revised thermodynamic database and test cases for calculating speciation of major, trace, and redox elements in natural water. USGS open fil rept. 91-183. http://h2o.usgs.gov/software/

Bemmelen, R.W. van, 1970. The Geology of Indonesia. General Geology of Indonesia and Adjacent Archipelagoes. Government Printing Office. The Haque

Budel, J. K. 1975. The Ice Age In The Tropics. Universitas, 1, 183-192.

Dam, M. A. C. 1994. The Late Quaternary Evolution Of The Bandung Basin, West-Java, Indonesia. Department Of Quaternary Geology, Faculty Of Earth Science, Vrije Universiteit, De Belelaan 1085, Amsterdam, 252 Pp.

Danes, J.V., 1910. Die Karstphanomene in Goenoeng Sewoe auf Java, Tjdschrift van het kon. Ned. Aardrijksk. Gen. Tweede Serie, deel XXVII, 247-260

Eckhardt K, 2005. How to construct recursive digital filters for baseflow separation. Hydrological Processes 19, 507-515.

Fakultas Kehutanan, 1993. Penyusunan Arahan Konservasi Tanah dan Air di Daerah Tangkapan Air Gua Bribin Kabupaten Gunung Kidul DIY. Kerjasama antara Dinas Kehutanan DIY - Fakultas Kehutanan UGM Yogyakarta

Flathe, H. , Pfeiffer, D., 1965. Grundzuge der morphologie, Geology und Hydrogeologie im Karstgebiet Gunung Sewu (Java, Indonesien): Geologisches Jahrbuch, v. 83, p. 533-562.

Gillieson, D., 1996, Caves: Processes, Development, and Management, Blackwell, Oxford

Haryono, E. dan Adji, T.N. 2004. Geomorfologi dan Hidrologi Karst. Yogyakarta: Kelompok Studi Karst, Fakultas Geografi, Universitas Gadjah Mada

Haryono, E. Day, M. , 2004. Landform differentiation within the Gunung Kidul Kegel karst, Java, Indonesia, Journal of Cave and Karst Studies, 66-August

Kusumayudha, S.B., 2005, Hidrogeologi Karst dan Geometri Fraktal di Daerah Gunungsewu, Adicita Karya Nusa, Yogyakarta

Lehmann, H., 1936. Morfologiche Studien auf Java, Gohr, Abh, 3, Stutgart

MacDonalds and Partners. 1984. Greater Yogyakarta - Groundwater Resources Study. Vol 3C: Cave Survey. Yogyakarta, Directorate General of Water Resources Development Project (P2AT)

Morley, J. 1982. Palaeoecological Interpretation Of A 10,000 Year Pollen Record From Danau Padang, Central Sumatra, Indonesia. Journal Of Biogeography, 9, 151-190.

Nathan RJ, McMahon TA, 1990. Evaluation of automated techniques for baseflow and recession analysis. Water Resources Research. 26(7):1465-1473.

Plummer,L.N., Prestemon,E.C. and Parkhurst, D.L., 1991. An Interactive Code (NETPATH) for modelling NET geochemical reactions along a flowPATH. U.S. Geological Survey, Water Resources Investigation. Rep. 91-4078, pp 130., http://h2o.usgs.gov/software/

Srijono dan Aldilla, N., 2006. Geogenesis Polje-Purba Ponjong Kabupaten Gunungkidul, Daerah Istimewa Yogyakarta, Gunung Sewu-Indonesian Cave and Karst Journal, Vol. 2 No. 1, HIKESPI, Indonesia

Stumn W., and J.J. Morgan. 1981. Aquatic Chemistry, $2^{\text {nd }}$ edition. New York:John Wiley and Sons

Surono, Toha, B., Sudarno, I., Wiryosujono, S., 1992, Geologi Lembar Surakarta-Giritontro, Jawa, Pusat Penelitian dan Pengembangan Geologi, Bandung

Suryanta, G., 2001, Kajian Karakteristik Hidrograf Satuan Daerah Karst Gunung Kidul (Studi Kasus: Daerah Tangkapan Air Sungai Bawahtanah Bribin, Kabupaten Gunung Kidul, Propinsi DIY), Skripsi Sarjana, Fakultas Geografi, UGM, Yogyakarta

Sutikno dan Tanudirjo, D., 2006. Kajian Geoarkeologi Kawasan Gunungsewu Sebagai Dasar Pengembangan Model Pelestarian Lingkungan Karst, Laporan Hasil Penelitian Hibah Penelitian Pasca Sarjana-HPTP, Universitas Gadjah Mada

Sweeting, M.M., 1972. Karst Landforms, Macmillan, London.

Urushibara-Yoshino, K. 1995. Environmental Change In The Karst Areas On The Island Of Java. Journal Of The Faculty Of Letters, Komazawa University, 53, 85-97.

Urushibara-Yoshino, K., Yoshino,M., 1997. Palaeoenvironmental change in Java Islands and its surrounding areas, Journal of Quaternary Science, 12 (5), 435-442

Verstappen, H. Th. 1975. On Palaeoclimates And Landform Development In Malesia. Modern Quaternary Research SE Asia, 1, 3-35.

Verstappen, H. Th. 1997. The effect of climatic change on southeast Asian geomorphology. J. Quaternary Sci., Vol. 12, 413-418.

Verstappen, H. Th., 1994. Climatic Change and Geomorphology In S. And Se Asia. Proceedings, Colloquim Royal Academy Of Overseas Sciences, Brussels, 1992. Geo-Eco-Trop 16, 101-147. 
Verstappen, H.Th., 1969. The state of karst research in Indonesia, in Stelcl, O., (ed.), Problems of the Karst Research, Brno, Ceskoslovenska Akademia Sciencias, p. 139-148.

Waltham, A.C., Smart, P.L., Friederich, H., Eavis, A.J. \& Atkinson, T.C., 1983, The caves of Gunung Sewu, Java: Cave Science, v. 10, no. 2, p. 55-96.

White, W.B., 1988. Geomorphology and Hydrology of Karst Terrain. Oxford University Press, New York 